\title{
ANALISIS TINGKAT KEPUASAN PESERTA DIDIK TERHADAP INSTITUSI PENDIDIKAN
}

\author{
Zul Azhar \\ Dosen Tetap Fakultas Ekonomi Universitas Pakuan \\ Lecturer of Economic Faculty at Pakuan University
}

\begin{abstract}
ABSTRAK
Institusi pendidikan merupakan bisnis jasa seperti bisnis pada umumnya yang harus mampu meningkatkan kualitas dan kuantitas pelayanan. Universitas Pakuan dalam upaya meningkatkan pelayanan senantiasa peka akan perubahan dan harus mampu menyediakan kurikulum yang tepat sesuai dengan kebutuhan user dan mengikuti perkembangan zaman. Tujuan penelitian ini adalah untuk mengetahui tingkat kepuasan mahasiswa/konsumen terhadap Universitas Pakuan. Dapat disimpulkan bahwa untuk informasi tentang Uinveritas Pakuan, dominan memilih jawaban baik yang dirata-ratakan $51,25 \%$. Untuk Penilaian terhadap staf pengajar, dominan memilih jawaban baik dengan nilai rata-rata $61.33 \%$. Untuk penilaian terhadap perpustakaan yang memilih jawaban baik dengan nilai yang diratakan 49,4\%. Kebersihan merupakan hal yang krusial karena umumnya memberikan jawan kurang baik atau tidak baik dengan nilai rata-rata masing-masing $47,5 \%$ dan $34,25 \%$ ( $81.75 \%$ persepsi tidak puas). Untuk ketersediaan lahan parkir umum menjawabnya baik denggan nilai rata-rata 52,5\%. Kinerja tata usaha juga sangat menentukan tingkat kepuasan mahasiswa, ternyata memberikan penilaian baik sebesar $58.5 \%$. Untuk sarana dan prasarana penilaian yang diberikan mahasiswa dari 9 item butir peranyaan ternyata yang berikan penilaian yang dominan adalah kutang baik dengan nilai sebesar rata-rata $55 \%$.
\end{abstract}

Kata kunci: Kualitas Pelayanan, Kepuasan Konsumen

\begin{abstract}
Educational institutions is a service business like a business in general should be able to improve the quality and quantity of services. Pakuan universities in an effort to improve service always sensitive to changes and should be able to provide a curriculum that is appropriate to the user needs and the times. The purpose of this study was to determine the level of student satisfaction / consumers against Pakuan University. It can be concluded that for information about Uinveritas Pakuan, dominant choose a good answer which averaged 51.25\%. For the assessment of the teaching staff, the dominant choose a good response with an average value of $61.33 \%$. For the assessment of the library choose a good answer to the value leveled $49.4 \%$. Hygiene is crucial because it generally gives jawan less well or not well with the average value respectively $47.5 \%$ and $34.25 \%$ (81.75\% dissatisfied perception). Availability of parking spaces for the general good answer denggan average value of 52.5\%. Performance administration also determine the level of student satisfaction, it gives a good assessment of 58.5\%. For facilities and infrastructure assessment given the students of 9 items grains peranyaan turns that give the dominant assessment is a good camisole with an average value of $55 \%$.
\end{abstract}

Keywords: Service Quality, Customer Satisfaction

\section{Pendahuluan}

Institusi pendidikan formal seperti perguruan tinggi sama dengan perusahaan pada umumnya. Guna menghadapi persaingan di era global dewasa ini khususnya menjelang diberlakukan Masyarakat Ekonomi Asean (MEA) harus mampu meningkatkan kualitas dan kuantitas baik dari segi pelayanan terhadap stakeholder, seperti mahasiswa, karyawan, dosen serta masyarakat. Dalam upaya meningkatkan kepuasan pelayanan tersebut institusi pendidikan seperti Universitas Pakuan harus terbuka dan mau mendengarkan kritikan, keluhan dan lain sebagainya dari semua pihak yang berkepentingan, senantiasa setiap saat harus mampu berubah dan menyediakan kurikulum sesuai 
kebutuhan dan perkembangan zaman. Pelayanan yang prima suatu keniscayaan, karena kualitas pelayanan merupakan perbandingan akan kenyataan yang diperoleh oleh pelangan/konsumen (Subagyo, 2010,11). Universitas Pakuan sebagai Universitas Swasta terbesar di Bogor harus mau berbenah, karena institusi dikatakan baik dan berkualitas jika mampu meningkatkan pelayanan, fasilitas yang memadai dan memenuhi kebutuhan para stateholdernya terutama mahasiswanya. Mutu pendidikan yang baik seperti kurikulum, buku kepustakaan dan sumber daya manusia seperti dosen dan karyawan kedepannya harus selalu meningkat sehingga masyarakat merasa puas.

Pelayanan dan fasilitas yang dimiliki suatu institusi akan mencermin baik buruknya kualitasnya. Pelayanan dan Fasilitas yang dapat memberikan tingkat kepuasan seperti:

1. Memiliki Sarana dan Prasarana yang memadai milik sendiri

2. Staf Tata Usaha yang ramah dan cekatan,

3. Tenaga kependidikan yang berkualitas,

4. Memiliki gedung serba guna,

5. Memiliki lapangan olahraga

6. Ruang kelas yang memadai yang dilengkapi dengan perlengkapan yang lain seperti LCD atau Infocus

7. Kamar kecil yang bersih dan apik yang tersedia disetiap lantai.

8. Lapangan Parkir yang luas dan memadai.

9. Perpustakaan yang lengkap
10. Sarana ibadah dan ATM centers, dan

11. Lahan hijau yang asri agar mahasiswa merasa nyaman diarea kampus yang sejuk.

Tujuan penelitian ini adalah untuk mengetahui tingkat kepuasan mahasiswa/konsumen terhadap Universitas Pakuan.

\section{Metode Penelitian}

Penarikan sample dalam penelitian ini dapat menjadi penentu kevalidan hasil penelitian. Teknik pengambilan sampel penelitian yang benar maka hasil penelitian dapat digeneralisasi kepada populasi. Metode penarikan sampel acak sederhana dengan jumlah sampel 120 responden dari enam fakultas yang ada di Universitas Pakuan.

Dalam penelitian ini terdapat dua variabel yang diwakilkan oleh huruf $\mathrm{X}$ dan $\mathrm{Y}$, dimana $\mathrm{X}$ merupakan pelayanan dan fasilitas untuk memberikan kepuasan kepada para mahasiswa, dan Y merupakan harapan mahasiswa. Penulis menggunakan metode uji Chi Square dengan tujuan untuk mengetahui besarnya pengaruh pelayanan terhadap harapan mahasiswa. Teknik statistika yang digunakan untuk menguji proporsi tiga atau lebih sampel penelitian yang terbagi dalam kelompok karakteristik tertentu (Sunyoto, 2012:203).

\section{Hasil dan Pembahasan}

3.1. Pengaruh usaha yang dilakukan keluarga besar Universitas Pakuan Untuk Meningkatkan Akreditasi disetiap Fakultas

Chi Square Test

\begin{tabular}{|l|c|c|c|}
\hline & value & $d f$ & $\begin{array}{c}\text { Asymp. Sign } \\
(2 \text { sided })\end{array}$ \\
\hline Pearson Chi Square & $16.454^{\mathrm{a}}$ & 15 & .353 \\
Likelihood Ratio & 14.352 & 15 & .499 \\
Linear by Linear Association & .775 & 1 & .379 \\
\hline
\end{tabular}

JIAFE (Jurnal Ilmiah Akuntansi Fakultas Ekonomi)

Volume 1 No. 1 Tahun 2015, Hal. 44-58 


\begin{tabular}{|l|c|l|l|}
\hline$N$ of Valid Cases & 120 & & \\
\hline $19 \operatorname{coll}(79.2 \%)$ bave & & \\
\hline
\end{tabular}

19 cell $(79.2 \%)$ have expected court less than 5. The minimun expected court is .20.

Interpretasi : Hubungan antara Usaha yang dilakukan keluarga besar Universitas Pakuan untuk meningkatkan akreditasi disetiap Fakultas memiliki nilai 0.353 artinya tidak ada pengaruhnya terhadap tingkat kepuasan

konsumen (mahasiswa) dikarenakan nilai $0.353 \geq 0.05$

\subsection{Pengaruh Sosialisasi Informasi Pendidikan yang diberikan oleh pihak Fakultas sampai kepada mahasiswa}

Chi Square Test

\begin{tabular}{|l|c|c|c|}
\hline & value & $d f$ & $\begin{array}{c}\text { Asymp. Sign } \\
\text { (2 sided) }\end{array}$ \\
\hline Pearson Chi Square & $15.521^{\mathrm{a}}$ & 10 & .114 \\
Likelihood Ratio & 14.308 & 10 & .159 \\
Linear by Linear Association & .000 & 1 & .996 \\
N of Valid Cases & 120 & & \\
\hline
\end{tabular}

12 cell $(66.7 \%)$ have expected court less than 5 . The minimun expected court is .10 .

Interpretasi : Hubungan Pengaruh Sosialisasi Informasi pendidikan yang diberikan oleh pihak Fakultas sampai kepada mahasiswa memiliki nilai 0.114 artinya tidak ada pengaruhnya terhadap kepuasan konsumen (mahasiswa) dikarenakan nilai $0.114 \geq 0.05$.

\subsection{Pengaruh Akses Informasi secara online dapat dengan mudah diperoleh mahasiswa}

Chi Square Test

\begin{tabular}{|l|c|c|c|}
\hline & value & $d f$ & $\begin{array}{c}\text { Asymp. Sign } \\
(2 \text { sided })\end{array}$ \\
\hline Pearson Chi Square & $20.526^{\mathrm{a}}$ & 15 & .153 \\
Likelihood Ratio & 20.644 & 15 & .149 \\
Linear by Linear Association & 5.642 & 1 & .018 \\
Nof Valid Cases & 120 & & \\
\hline
\end{tabular}

21 cell $(87.5 \%)$ have expected court less than 5 . The minimun expected court is .10 .

Interpretasi : Hubungan pengaruh akses informasi secara online dapat dengan mudah diperoleh mahasiswa memiliki nilai 0.153 artinya tidak ada pengaruhnya atau tidak ada hubungannya terhadap tingkat kepuasan konsumen (mahasiswa) karena nilai $0.153 \geq 0.05$.

\subsection{Pengaruh Informasi SIMAK Universitas Pakuan sudah efektif bagi mahsiswa setiap Fakultas}

Chi Square Test

\begin{tabular}{|l|c|c|c|}
\hline & value & $d f$ & $\begin{array}{c}\text { Asymp. Sign } \\
(2 \text { sided })\end{array}$ \\
\hline Pearson Chi Square & $32.414^{\mathrm{a}}$ & 15 & .006 \\
\hline
\end{tabular}




\begin{tabular}{|l|c|c|c|}
\hline Likelihood Ratio & 32.066 & 15 & .006 \\
Linear by Linear Association & 5.278 & 1 & .022 \\
N of Valid Cases & 120 & & \\
\hline
\end{tabular}

20 cells $(83.3 \%)$ have expected court less than 5. The minimun expected court is .10 .

Interpretasi : Hubungan antara Informasi SIMAK Universitas Pakuan sudah efektif bagi mahasiswa disetiap Fakultas memiliki nilai 0.006 artinya ada hubungannya dengan tingkat kepuasan konsumen (mahasiswa) karena nilai $0.006 \leq 0.05$

\subsection{Pengaruh Penyampaian Materi Perkulihan Oleh Dosen sesuai dengan bidang Pengetahuannya}

Chi Square Test

\begin{tabular}{|l|c|c|c|}
\hline & value & $d f$ & $\begin{array}{c}\text { Asymp. Sign } \\
(2 \text { sided })\end{array}$ \\
\hline Pearson Chi Square & $15.393^{\mathrm{a}}$ & 15 & .118 \\
Likelihood Ratio & 17.243 & 15 & .069 \\
Linear by Linear Association & .005 & 1 & .944 \\
Nof Valid Cases & 120 & & \\
\hline
\end{tabular}

13 cells $(72.2 \%)$ have expected court less than 5. The minimun expected court is .60.

Interpretasi : Hubungan antara Penyampaian materi perkuliahan oleh dosen sesuai dengan bidang pengetahuannya memiliki nilai 0.118 artinya tidak ada hubungan terhadap kepuasan konsumen karena nilai 0.118 $\geq 0.05$

\subsection{Pengaruh Persiapan Materi Kuliah yang baik oleh Desen sebelum menyampaikan kepada mahasiswa disetiap Fakultas}

Chi Square Test

\begin{tabular}{|l|c|c|c|}
\hline & value & $d f$ & $\begin{array}{c}\text { Asymp. Sign } \\
(2 \text { sided })\end{array}$ \\
\hline Pearson Chi Square & $25.747^{\mathrm{a}}$ & 10 & .004 \\
Likelihood Ratio & 29.434 & 10 & .001 \\
Linear by Linear Association & 1.475 & 1 & .225 \\
Nof Valid Cases & 120 & & \\
\hline
\end{tabular}

13 cell $(72.2 \%)$ have expected court less than 5 . The minimun expected court is .30 .

Interpretasi : Hubungan antara persiapan materi kuliah yang baik oleh dosen sebelum menyampaikan kepada mahasiswa disetiap fakultas memiliki nilai 0.004 artinya ada hubungan terhadap tingkat kepuasan konsumen karena nilai $0.04=<0.05$

\subsection{Pengaruh Dosen Datang Tepat waktu Kedalam Kelas disetiap Fakultas}


Chi Square Test

\begin{tabular}{|l|c|c|c|}
\hline & value & $d f$ & $\begin{array}{c}\text { Asymp. Sign } \\
(2 \text { sided })\end{array}$ \\
\hline Pearson Chi Square & $23.775^{\mathrm{a}}$ & 15 & .069 \\
Likelihood Ratio & 27.989 & 15 & .022 \\
Linear by Linear Association & 1.121 & 1 & .290 \\
Nof Valid Cases & 120 & & \\
\hline
\end{tabular}

20 cells $(83.3 \%)$ have expected court less than 5. The minimun expected court is .10.

Interpretasi : Hubungan antara dosen datang tepat waktu kedalam kelas memiliki nilai 0.069 artinya tidak ada hubungan terhadap tingkat kepuasan konumen/mahasiswa karena nilai 0.069 $\geq 0.05$

\subsection{Pengaruh Kemampuan dosen Dalam Mengaplikasikan Materi yangg diajarkan kedalam Kehidupan sehari-hari disetiap Fakultas}

Chi Square Test

\begin{tabular}{|l|c|c|c|}
\hline & value & $d f$ & $\begin{array}{c}\text { Asymp. Sign } \\
(2 \text { sided })\end{array}$ \\
\hline Pearson Chi Square & $23.870^{\mathrm{a}}$ & 15 & .067 \\
Likelihood Ratio & 22.553 & 15 & .094 \\
Linear by Linear Association & .337 & 1 & .562 \\
Nof Valid Cases & 120 & & \\
\hline
\end{tabular}

19 cell $(79.2 \%)$ have expected court less than 5 . The minimun expected court is .10 .

Interpretasi : Hubungan antara kepuasan konsumen karena nilai 0.067 kemampuan dosen dalam $\geq 0.05$. mengaplikasikan materi yang diajarkan kedalam kehidupan sehari-hari disetiap fakultas memiliki nilai 0.067 artinya tada ada hubungannya terhadap tingkat

\subsection{Pengaruh Sistem Penilaian yang diberikan Dosen kepada Mahasiswanya disetiap Fakultas}

Chi Square Test

\begin{tabular}{|l|c|c|c|}
\hline & value & $d f$ & $\begin{array}{c}\text { Asymp. Sign } \\
(2 \text { sided })\end{array}$ \\
\hline Pearson Chi Square & $8.655^{\mathrm{a}}$ & 10 & .565 \\
Likelihood Ratio & 7.530 & 10 & .675 \\
Linear by Linear Association & .113 & 1 & .737 \\
Nof Valid Cases & 120 & & \\
\hline
\end{tabular}

13 cell $(72.2 \%)$ have expected court less than 5. The minimun expected court is .10.

Interpretasi : Hubungan antara sistem penilaian yang diberikan dosen kepada mahasiswanya disetiap fakultas memiliki nilai 0.565 artinya tidak ada hubungannya terhadap tingkat kepuasan $\begin{array}{lrr}\text { 3.10. Pengaruh } & \text { Kegiatan } & \text { Belajar } \\ \text { Mengajar } & \text { yang Dosen berikan } \\ \text { kepada } & \text { Mahasiswa }\end{array}$ konsumen karena nilai $0.565 \geq 0.05$ 
Chi Square Test

\begin{tabular}{|l|c|c|c|}
\hline & value & Df & $\begin{array}{c}\text { Asymp. Sign } \\
\text { (2 sided) }\end{array}$ \\
\hline Pearson Chi Square & $6.211^{\mathrm{a}}$ & 10 & .797 \\
Likelihood Ratio & 7.099 & 10 & .716 \\
Linear by Linear Association & 1.196 & 1 & .274 \\
Nof Valid Cases & 120 & & \\
\hline
\end{tabular}

13 cell $(72.2 \%)$ have expected court less than 5 . The minimun expected court is .40 .

Interpretasi : Hubungan antara kegiatan belajar mengajar yang dosen berikan kepada mahasiswanya memiliki nilai 0.797 artinya tidak ada hubungannya terhadap tingkat kepuasan konsumen

3.11. Pengaruh Interaksi antara Dosen dengan Mahasiswa disetiap Fakultas karena nilai $0.797 \geq 0.05$.

Chi Square Test

\begin{tabular}{|l|c|c|c|}
\hline & Value & $d f$ & $\begin{array}{c}\text { Asymp. Sign } \\
(2 \text { sided })\end{array}$ \\
\hline Pearson Chi Square & $20.721^{\mathrm{a}}$ & 15 & .146 \\
Likelihood Ratio & 18.915 & 15 & .218 \\
Linear by Linear Association & 1.065 & 1 & .302 \\
Nof Valid Cases & 120 & & \\
\hline
\end{tabular}

19 cell $(79.2 \%)$ have expected court less than 5. The minimun expected court is .10.

Interpretasi : Hubungan antara interaksi dosen dengan mahasiswa memiliki nilai 0.146 artinya tidak ada hubungannya terhadap tingkat kepuasan konsumen karena nilai $0.146 \geq 0.05$

\subsection{Pengaruh Asisten Laboratorium sudah memeberikan materi yang sesuai disetiap Fakultas}

Chi Square Test

\begin{tabular}{|l|c|c|c|}
\hline & value & $d f$ & $\begin{array}{c}\text { Asymp. Sign } \\
(2 \text { sided })\end{array}$ \\
\hline Pearson Chi Square & $17.279^{\mathrm{a}}$ & 15 & .302 \\
Likelihood Ratio & 18.079 & 15 & .259 \\
Linear by Linear Association & 1.054 & 1 & .305 \\
Nof Valid Cases & 120 & & \\
\hline
\end{tabular}

18 cell $(75.0 \%)$ have expected court less than 5. The minimun expected court is .20.

Interpretasi : hubungan antara asisten laboratorium sudah memberikan materi yang sesuai atau tepat disetiap fakultas memiliki nilai 0.302 artinya tidak ada hubungannya terhadap tingkat kepuasan

3.13. Pengaruh Asisten Laboratorium sudah menjadi teman dalam mengajar disetiap Fakultas

konsumen karena niai $0.302 \geq 0.05$ 
Chi Square Test

\begin{tabular}{|l|c|c|c|}
\hline & value & Df & $\begin{array}{c}\text { Asymp. Sign } \\
\text { (2 sided) }\end{array}$ \\
\hline Pearson Chi Square & $31.643^{\mathrm{a}}$ & 15 & .007 \\
Likelihood Ratio & 33.878 & 15 & .004 \\
Linear by Linear Association & .379 & 1 & .538 \\
Nof Valid Cases & 120 & & \\
\hline
\end{tabular}

19 cells $(79.2 \%)$ have expected court less than 5. The minimun expected court is .20.

Interpretasi : hubungan antara asisten lab sudah menjadi teman dalam belajar mengajar disetiap fakultas memiliki nilai 0.007 artinya ada hubungannya terhadap tingkat kepuasan konsumen karena nilai

\subsection{Pengaruh Petugas Perpustakaan Melakukan Pelayanan dengan Cepat} $0.007 \leq 0.05$.

Chi Square Test

\begin{tabular}{|l|c|c|c|}
\hline & value & Df & $\begin{array}{c}\text { Asymp. Sign } \\
(2 \text { sided })\end{array}$ \\
\hline Pearson Chi Square & $15.971^{\mathrm{a}}$ & 15 & .384 \\
Likelihood Ratio & 15.554 & 15 & .412 \\
Linear by Linear Association & 018 & 1 & .895 \\
Nof Valid Cases & 120 & & \\
\hline
\end{tabular}

19 cell $(79.2 \%)$ have expected court less than 5. The minimun expected court is .10.

Interpretasi : Hubungan antara petugas perpustakaan mengerjakan atau memberikan pelayanan dengan cepat memiliki nilai 0.384 artinya tidak ada hubungannya terhadap tingkat kepuasan konsumen karena nilai $0.384 \geq 0.05$

\subsection{Pengaruh Kelengkapan Buku yang ada disetiap Fakultas sudah Memenuhi Kebutuhan Mahasiswa disetiap fakultas}

Chi Square Test

\begin{tabular}{|l|c|c|c|}
\hline & value & Df & $\begin{array}{c}\text { Asymp. Sign } \\
(2 \text { sided })\end{array}$ \\
\hline Pearson Chi Square & $27.099^{\mathrm{a}}$ & 15 & .028 \\
Likelihood Ratio & 22.726 & 15 & .090 \\
Linear by Linear Association & 2.747 & 1 & .097 \\
Nof Valid Cases & 120 & & \\
\hline
\end{tabular}

20 cells $(83.3 \%)$ have expected court less than 5. The minimun expected court is .10.

Interpretasi : Hubungan antara kelengkapan buku yang ada di setiap fakultas sudah memenuhi kebutuhan mahasiswa memiliki nilai 0.028 artinya ada hubungannya terhadap tingkat kepuasan konsumen karena nilai $0.028 \leq$ 0.05

\subsection{Pengaruh Buku-buku sudah tersimpan atau tertata dengan}


Chi Square Test

\begin{tabular}{|l|c|c|c|}
\hline & value & Df & $\begin{array}{c}\text { Asymp. Sign } \\
\text { (2 sided) }\end{array}$ \\
\hline Pearson Chi Square & $17.421^{\mathrm{a}}$ & 15 & .294 \\
Likelihood Ratio & 16.495 & 15 & .350 \\
Linear by Linear Association & .241 & 1 & .623 \\
Nof Valid Cases & 120 & & \\
\hline
\end{tabular}

19 cells $(79.2 \%)$ have expected court less than 5. The minimun expected court is .10 .

Interpretasi : Hubungan antara bukubuku sudah tersimpan atau tertata rapi sesuai dengan rak buku disetiap fakultas memiliki nilai 0.294 artinya tidak ada hubungannya terhadap tingkat kepuasan

\subsection{Pengaruh Kenyamanan saat belajar diperperpustakaan disetiap Fakultas}

Chi Square Test

\begin{tabular}{|l|c|c|c|}
\hline & value & Df & $\begin{array}{c}\text { Asymp. Sign } \\
(2 \text { sided })\end{array}$ \\
\hline Pearson Chi Square & $13.872^{\mathrm{a}}$ & 15 & .535 \\
Likelihood Ratio & 17.750 & 15 & .276 \\
Linear by Linear Association & 1.460 & 1 & .227 \\
Nof Valid Cases & 120 & & \\
\hline
\end{tabular}

19 cell $(79.2 \%)$ have expected court less than 5. The minimun expected court is . 30 .

Interpretasi : Hubungan antara kenyamanan saat belajar diperpustakaan memiliki nilai 0.535 artinya tidak ada hubungan terhadap tingkat kepuasan konsumen karena nilai $0.535 \geq 0.05$

\subsection{Pengaruh Tempat Penyimpanan tas sudah mencukupi diperpustakaan disetiap Fakultas}

Chi Square Test

\begin{tabular}{|l|c|c|c|}
\hline & value & Df & $\begin{array}{c}\text { Asymp. Sign } \\
(2 \text { sided })\end{array}$ \\
\hline Pearson Chi Square & $17.438^{\mathrm{a}}$ & 15 & .293 \\
Likelihood Ratio & 20.504 & 15 & .153 \\
Linear by Linear Association & 1.719 & 1 & .190 \\
Nof Valid Cases & 120 & & \\
\hline
\end{tabular}

22 cells $(91.7 \%)$ have expected court less than 5. The minimun expected court is .23.

Interpretasi : Hubungan antara tempat penyimpanan tas sudah mencukupi di perpustakaan disetiap fakultas memiliki nilai 0.293 artinya tidak ada hubungan terhadap tingkat kepuasan konsumen karena nilai $0.293 \geq 0.05$ 


\subsection{Pengaruh Tingkat Kebersihan Dilingkungan Universitas}

\section{Pakuan}

Chi Square Test

\begin{tabular}{|l|c|c|c|}
\hline & value & $d f$ & $\begin{array}{c}\text { Asymp. Sign } \\
(2 \text { sided })\end{array}$ \\
\hline Pearson Chi Square & $21,338^{\mathrm{a}}$ & 15 & .126 \\
Likelihood Ratio & 21.274 & 15 & .128 \\
Linear by Linear Association & 1.103 & 1 & .294 \\
Nof Valid Cases & 120 & & \\
\hline
\end{tabular}

20 cells $(83.3 \%)$ have expected court less than 5. The minimun expected court is .10.

Interpretasi : Hubungan antara tingkat kebersihan di lingkungan universitas Pakuan memiliki nilai 0.126 artinya tidak ada hubungan terhadap tingkat kepuasan konsumenkarena nilai $0.126 \geq$

\subsection{Pengaruh Banyak tempat sampah tersedia disetiap Fakultas} 0.05

Chi Square Test

\begin{tabular}{|l|c|c|c|}
\hline & value & $d f$ & $\begin{array}{c}\text { Asymp. Sign } \\
(2 \text { sided })\end{array}$ \\
\hline Pearson Chi Square & $17.708^{\mathrm{a}}$ & 15 & .278 \\
Likelihood Ratio & 20.253 & 15 & .162 \\
Linear by Linear Association & .144 & 1 & .705 \\
Nof Valid Cases & 120 & & \\
\hline
\end{tabular}

19 cell $(79.2 \%)$ have expected court less than 5. The minimun expected court is .20.

Interpretasi : Hubungan antara banyak tempat sampah yang tersedia di setiap Fakultas di Universitas Pakuan memiliki nilai 0278 artinya tidak ada hubungannya terhadap tingkat kepuasan konsumen karena nilai $0.278 \geq 0.05$

\subsection{Pengaruh Jumlah Toilet yang tersedia sudah mencukup kebutuhan mahasiswa disetiap Fakultas}

Chi Square Test

\begin{tabular}{|l|c|c|c|}
\hline & value & $d f$ & $\begin{array}{c}\text { Asymp. Sign } \\
(2 \text { sided })\end{array}$ \\
\hline Pearson Chi Square & $13.560^{\mathrm{a}}$ & 10 & .011 \\
Likelihood Ratio & 15.627 & 10 & .111 \\
Linear by Linear Association & .001 & 1 & .973 \\
Nof Valid Cases & 120 & & \\
\hline
\end{tabular}

13 cells $(72.2 \%)$ have expected court less than 5 . The minimun expected court is .50 .

Interpretasi : Hubungan antara jumlah toilet yang tersedia sudah mencukupi kebutuhan mahasiswa memiliki nilai
0.011 artinya ada hubungan terhadap tingkat kepuasan konsumen karena nilai $0.011 \leq 0.05$ 


\subsection{Pengaruh Toilet yang tersedia sudah bersih disetiap Fakultas}

Chi Square Test

\begin{tabular}{|l|c|c|c|}
\hline & value & $d f$ & $\begin{array}{c}\text { Asymp. Sign } \\
(2 \text { sided })\end{array}$ \\
\hline Pearson Chi Square & $17.690^{\mathrm{a}}$ & 15 & .030 \\
Likelihood Ratio & 18.590 & 15 & .046 \\
Linear by Linear Association & 2.057 & 1 & .151 \\
Nof Valid Cases & 120 & & \\
\hline
\end{tabular}

14 cells $(77.8 \%)$ have expected court less than 5 . The minimun expected court is .80 .

Interpretasi : Hubungan antara toilet yang tersedia sudah bersih disetiap fakultas memiliki nilai 0.030 artinya ada hubungannya terhadap tingkat kepuasan konsumen karena nilai $0.03 \leq 0.05$
3.23. Pengaruh Lahan Parkir sudah cukup memadai untuk parkiran kendaraan yang dipakai oleh mahasiswa dan dosen

Chi Square Test

\begin{tabular}{|l|c|c|c|}
\hline & Value & $d f$ & $\begin{array}{c}\text { Asymp. Sign } \\
(2 \text { sided })\end{array}$ \\
\hline Pearson Chi Square & $15.478^{\mathrm{a}}$ & 15 & .418 \\
Likelihood Ratio & 11.086 & 15 & .746 \\
Linear by Linear Association & 2.550 & 1 & .110 \\
Nof Valid Cases & 120 & & \\
\hline
\end{tabular}

20 cells $(83.3 \%)$ have expected court less than 5. The minimun expected court is .10.

Interpretasi : Hubungan antara lahan parkir cukup memadai untuk parkiran mahasiswa dan dosen memiliki nilai 0.418 artinya tidak ada hubungan terhadap tingkat kepuasan konsumen karena nilai $0.418 \geq 0.05$

\subsection{Pengaruh Keamanan Kendaraan sudah terjamin}

Chi Square Test

\begin{tabular}{|l|c|c|c|}
\hline & Value & $d f$ & $\begin{array}{c}\text { Asymp. Sign } \\
(2 \text { sided })\end{array}$ \\
\hline Pearson Chi Square & $21.574^{\mathrm{a}}$ & 15 & .119 \\
Likelihood Ratio & 19.645 & 15 & .186 \\
Linear by Linear Association & 2.840 & 1 & .092 \\
Nof Valid Cases & 120 & & \\
\hline
\end{tabular}

21 cells $(87.5 \%)$ have expected court less than 5 . The minimun expected court is .30 .

Interpretasi : Hubungan antara keamanan kendaraan sudah terjamin memiliki nilai 0.119 artinya tidak ada hubungan terhadap tingkat kepuasan konsumen karena nilai $0.119 \geq 0.05$

\subsection{Pengaruh Kinerja Karyawan Tata Usaha setiap Fakultas di Universitas}


Chi Square Test

\begin{tabular}{|l|c|c|c|}
\hline & Value & $d f$ & $\begin{array}{c}\text { Asymp. Sign } \\
(2 \text { sided })\end{array}$ \\
\hline Pearson Chi Square & $19.287^{\mathrm{a}}$ & 15 & .201 \\
Likelihood Ratio & 18.000 & 15 & .253 \\
Linear by Linear Association & 0.493 & 1 & .483 \\
Nof Valid Cases & 120 & & \\
\hline
\end{tabular}

a. $\quad 21$ cells $(79.2 \%)$ have expected court less than 5. The minimun expected court is .10 .

Interpretasi : Hubungan antara kinerja karyawan tata usaha setiap fakultas di Universitas Pakuan memiliki nilai 0,201 artinya tidak ada hubungannya terhadap tingkat kepuasan konsumen karena nilai $0.201 \geq 0.05$

\subsection{Pengaruh Staf-staf TU sudah memberikan informasi yang dibutuhkan oleh mahasiswa}

Chi Square Test

\begin{tabular}{|l|c|c|c|}
\hline & Value & Df & $\begin{array}{c}\text { Asymp. Sign } \\
(2 \text { sided })\end{array}$ \\
\hline Pearson Chi Square & $19.125^{\mathrm{a}}$ & 15 & .208 \\
Likelihood Ratio & 18.765 & 15 & .225 \\
Linear by Linear Association & 1.291 & 1 & .256 \\
Nof Valid Cases & 120 & & \\
\hline
\end{tabular}

19 cell $(79.2 \%)$ have expected court less than 5 . The minimun expected court is .10 .

Interpretasi : Hubungan staf-staf TU sudah memberikan informasi yang dibutuhkan oleh mahasiswa memiliki nilai 0.208 artinya tidak ada hubungannya terhadap tingkat kepuasan konsumen karena nilai $0.208 \geq 0.05$

\subsection{Pengaruh Mahasiswa yang sudah memiliki rasa kepedulian untuk menjaga kebersihan lingkungan}

Chi Square Test

\begin{tabular}{|l|c|c|c|}
\hline & value & Df & $\begin{array}{c}\text { Asymp. Sign } \\
\text { (2 sided) }\end{array}$ \\
\hline Pearson Chi Square & $12.595^{\mathrm{a}}$ & 15 & .634 \\
Likelihood Ratio & 15.391 & 15 & .424 \\
Linear by Linear Association & .737 & 1 & .256 \\
Nof Valid Cases & 120 & & \\
\hline
\end{tabular}

19 cell $(79.2 \%)$ have expected court less than 5. The minimun expected court is .10.

Interpretasi : Hubungan antara mahasiswa suudah memiliki rasa kepedulian untuk menjaga kebersihan lingkungan memiliki nilai 0.634 artinya tidak ada hubungannya terhadap tingkat kepuasan konsumen karena nilai 0.634 $\geq 0.05$ 
Chi Square Test

\begin{tabular}{|l|c|c|c|}
\hline & value & $d f$ & $\begin{array}{c}\text { Asymp. Sign } \\
(2 \text { sided })\end{array}$ \\
\hline Pearson Chi Square & $17.579^{\mathrm{a}}$ & 15 & .285 \\
Likelihood Ratio & 18.131 & 15 & .256 \\
Linear by Linear Association & 1.276 & 1 & .241 \\
Nof Valid Cases & 120 & & \\
\hline
\end{tabular}

19 cell $(79.2 \%)$ have expected court less than 5. The minimun expected court is .20 .

Interpretasi : Hubungan antara ruangan belajar mengajar sudah memiliki nilai 0.285 artinya tidak ada hubungannya terhadap tingkat kepuasan konsumen

3.29. Pengaruh Kenyamanan Ruang Belajar Mengajar karena nilai $0.285 \geq 0.05$

Chi Square Test

\begin{tabular}{|l|c|c|c|}
\hline & value & $d f$ & $\begin{array}{c}\text { Asymp. Sign } \\
(2 \text { sided })\end{array}$ \\
\hline Pearson Chi Square & $22.523^{\mathrm{a}}$ & 15 & .095 \\
Likelihood Ratio & 22.239 & 15 & .102 \\
Linear by Linear Association & 5.167 & 1 & .023 \\
Nof Valid Cases & 120 & & \\
\hline
\end{tabular}

19 cell $(79.2 \%)$ have expected court less than 5. The minimun expected court is .10.

Interpretasi : Pengaruh antara kenyamanan ruangan belajar mengajar memiliki nilai 0.095 artinya tidak ada hubungannya terhadap tingkat kepuasan konsumen karena nilai $0.095 \geq 0.05$
3.30. Pengaruh Fasilitas-fasilitas ruangan belajar (LCD/Infocus) sudah menunjang Pembelajaran di kelas

Chi Square Test

\begin{tabular}{|l|c|c|c|}
\hline & value & Df & $\begin{array}{c}\text { Asymp. Sign } \\
(2 \text { sided })\end{array}$ \\
\hline Pearson Chi Square & $26.188^{\mathrm{a}}$ & 15 & .036 \\
Likelihood Ratio & 28.193 & 15 & .019 \\
Linear by Linear Association & .911 & 1 & .340 \\
Nof Valid Cases & 120 & & \\
\hline
\end{tabular}

19 cell $(79.2 \%)$ have expected court less than 5. The minimun expected court is .20.

Interpretasi : hubungan antara fasilitasfasilitas ruang belajar (LCD/Infocus) sudah menunjang pembelajaran dikelas memiliki nilai 0.036 artinya ada hubungan dengan tingkat kepuasan 3.31. Pengaruh Proses Pembangunan
gedung baru mengganggu
Perkuliahan dan Ujian konsumen karena nilai $0.036 \leq 0.05$ 
Chi Square Test

\begin{tabular}{|l|c|c|c|}
\hline & value & Df & $\begin{array}{c}\text { Asymp. Sign } \\
\text { (2 sided) }\end{array}$ \\
\hline Pearson Chi Square & $12.887^{\mathrm{a}}$ & 15 & .611 \\
Likelihood Ratio & 14.076 & 15 & .520 \\
Linear by Linear Association & 1.781 & 1 & .182 \\
Nof Valid Cases & 120 & & \\
\hline
\end{tabular}

22 cells $(91.7 \%)$ have expected court less than 5. The minimun expected court is . 30 .

Interpretasi : Hubungan antara pengaruh proses pembangunan gedung baru mengganggu perkuliahan dan ujian memiliki nilai 0.611 artinya tidak ada hubungannya terhadap tingkat kepuasan konsumen karena nilai $0.611 \geq 0.05$

\subsection{Pengaruh Tersedianya kantin yang efektif dan efisien}

Chi Square Test

\begin{tabular}{|l|c|c|c|}
\hline & value & $d f$ & $\begin{array}{c}\text { Asymp. Sign } \\
(2 \text { sided })\end{array}$ \\
\hline Pearson Chi Square & $8.960^{\mathrm{a}}$ & 10 & .536 \\
Likelihood Ratio & 9.477 & 10 & .488 \\
Linear by Linear Association & .078 & 1 & .780 \\
Nof Valid Cases & 120 & & \\
\hline
\end{tabular}

22 cells $(91.7 \%)$ have expected court less than 5. The minimun expected court is .30.

Interpretasi : Hubungan antara tersedianya kantin yang efektif dan efisien memiliki nilai 0.536 artinya tidak ada hubungannya terhadap tingkat kepuasan konsumen karena nilai $0.536 \geq$ 0.05
3.33. Pengaruh adanya kegiatan mahasiswa seperti mengadakan acara band dan sejenis, dapat mengganggu perkuliahan kegiatan

Chi Square Test

\begin{tabular}{|l|c|c|c|}
\hline & value & $d f$ & $\begin{array}{c}\text { Asymp. Sign } \\
(2 \text { sided })\end{array}$ \\
\hline Pearson Chi Square & $9.618^{\mathrm{a}}$ & 15 & .843 \\
Likelihood Ratio & 11.350 & 15 & .727 \\
Linear by Linear Association & .771 & 1 & .380 \\
N of Valid Cases & 120 & & \\
\hline
\end{tabular}

19 cell $(79.2 \%)$ have expected court less than 5. The minimun expected court is .20.

Interpretasi : Hubungan antara adanya kegiatan mahasiswa seperti mengadakan acara band dan sejenisnya, dapat mengganggu kegiatan perkuliahan memiliki nilai 0,843 artinya tidak ada hubungannya terhadap tingkat kepuasan konsumen karena nilai $0,843 \geq 0.05$

\subsection{Pengaruh Ketersediaan Ruang Terbuka Hijau}


Chi Square Test

\begin{tabular}{|l|c|c|c|}
\hline & value & $d f$ & $\begin{array}{c}\text { Asymp. Sign } \\
(2 \text { sided })\end{array}$ \\
\hline Pearson Chi Square & $19.505^{\mathrm{a}}$ & 15 & .192 \\
Likelihood Ratio & 22.143 & 15 & .104 \\
Linear by Linear Association & .946 & 1 & .331 \\
N of Valid Cases & 120 & & \\
\hline
\end{tabular}

19 cell $(79.2 \%)$ have expected court less than 5. The minimun expected court is .20.

Interpretasi : Hubungan antara ketersediaan ruang terbuka hijau memiliki nilai 0.192 , artinya tidak ada hubungannya terhadap tingkat kepuasan konsumen karena nilai $0.192 \geq 0.05$

\subsection{Pengaruh Kepuasan Mahasiswa atas pelayanan yang diberikan oleh Universitas Pakuan}

Chi Square Test

\begin{tabular}{|l|c|c|c|}
\hline & value & $d f$ & $\begin{array}{c}\text { Asymp. Sign } \\
(2 \text { sided })\end{array}$ \\
\hline Pearson Chi Square & $16.213^{\mathrm{a}}$ & 15 & .368 \\
Likelihood Ratio & 16.750 & 15 & .334 \\
Linear by Linear Association & 3.051 & 1 & .081 \\
Nof Valid Cases & 120 & & \\
\hline
\end{tabular}

19 cell $(79.2 \%)$ have expected court less than 5. The minimun expected court is .20.

Interpretasi : Hubungan antara Kepuasan Mahasiswa atas pelayanan yang diberikan oleh Universitas Pakuan memiliki nilai 0.363 , artinya tidak ada hubungannya terhadap timgkat kepuasan konsumen karena nilai $0.363 \geq 0.05$.

\section{Kesimpulan}

Dari hasil penelitian yang telah dilakukan di atas dapat disimpulkan bahwa untuk informasi tentang Universitas Pakuan, dominan memilih jawaban baik yang dirata-ratakan $51,25 \%$. Untuk Penilaian terhadap staf pengajar, dominan memilih jawaban baik dengan nilai rata-rata $61.33 \%$. Untuk penilaian terhadap perpustakaan yang memilih jawaban baik dengan nilai yang diratakan 49,4\%. Kebersihan merupakan hal yang krusial karena umumnya memberikan jawan kurang baik atau tidak baik dengan nilai ratarata masing-masing $47,5 \%$ dan $34,25 \%$ (81.75\% persepsi tidak puas). Untuk ketersediaan lahan parkir umum menjawabnya baik denggan nilai ratarata $52,5 \%$. Kinerja tata usaha juga sangat menentukan tingkat kepuasan mahasiswa, ternyata memberikan penilaian baik sebesar $58.5 \%$. Untuk sarana dan prasarana penilaian yang diberikan mahasiswa dari 9 item butir peranyaan ternyata yang berikan penilaian yang dominan adalah kutang baik dengan nilai sebesar rata-rata $55 \%$.

\section{Daftar Pustaka}

Denis, Walker. 2011. Mendahulukan Kepuasan Pelanggan, Binarupa Aksara, Tangerang Selatan,

Hidayat, Syah. 2010. Pengantar Umum Metode Penelitian Pendidikan Pendekatan Verivikasi, Suska Pers, Pekan Baru.

Nasehudin, Toto Syatori dan Nanang Gozali. 2012. Metode Penelitian Kuantitatif, CV. Pustaka Setia, Jakarta. 
Kotler, Philip dan Amstrong. 2009. Prinsip-prinsip Pemasaran, Edisi 12, PT. Indeks Jakarta.

Kotler, Philip dan Kevin Lane Keller. 2010. Manajemen Pemasaran, Edisi 13 , PT. Indeks, Jakarta.

Sarwono, Jonathan. 2012. Metode Riset Skripsi Pendekatan Kuantitatif Menggunakan Prosedur SPSS, PT. Elex Media Komputindo, Jakarta.

Sugiyono. 2011. Metode Penelitian Kuantitatif dan Kualitatif, Alfabeta, Bandung.

Sunyoto, Danang. 2013. Dasar-dasar Manajemen Pemasaran, Konsep, Strategi dan Kasus, CAPS. Yogyakarta.

Sunyoto, Danang. 2013. Dasar-dasar Manajemen Pemasaran, CAPS, Yogyakarta.

Subagyo, Ahmad. 2010. Marketing in Busines, Mitra Wacana Media, Jakarta.

Tjiptono, Fandi. 2012. Service Managemen, Edisi 2, CV. Andi Offset, Yogyakarta.

Umar, Husein. 2013. Metode Penelitian Untuk Skripsi dan tesis Bisnis, Raja Grafindo Persada. Yogyakarta. 